\title{
Bio-Based Polyisoprene Can Mitigate Climate Change and Deforestation in Expanding Rubber Production
}

\author{
Rahamim Batten ${ }^{1}$, Mukund Karanjikar ${ }^{2}$ and Sabrina Spatari ${ }^{1, *(D)}$ \\ 1 Faculty of Civil and Environmental Engineering, Technion-Israel Institute of Technology, \\ Haifa 3200003, Israel; rahamimb@campus.technion.ac.il \\ 2 Technology Holding LLC, Salt Lake City, UT 84119, USA; mukund@tekholding.com \\ * Correspondence: ssabrina@technion.ac.il
}

Citation: Batten, R.; Karanjikar, M Spatari, S. Bio-Based Polyisoprene Can Mitigate Climate Change and Deforestation in Expanding Rubber Production. Fermentation 2021, 7, 204. https://doi.org/10.3390/fermentation 7040204

Academic Editor: Francesco Grieco

Received: 10 August 2021

Accepted: 15 September 2021

Published: 23 September 2021

Publisher's Note: MDPI stays neutral with regard to jurisdictional claims in published maps and institutional affiliations.

Copyright: (c) 2021 by the authors. Licensee MDPI, Basel, Switzerland. This article is an open access article distributed under the terms and conditions of the Creative Commons Attribution (CC BY) license (https:// creativecommons.org/licenses/by/ $4.0 /)$.

\begin{abstract}
Biomass is a promising renewable feedstock to produce polyisoprene for the rubber industry. Through metabolic engineering, sugars derived from pretreated and hydrolyzed cellulose and hemicellulose can be directly fermented to isoprene to produce rubber. Here we investigate the life cycle environmental impact of isoprene fermentation to produce bio-polyisoprene from agricultural residues (of Zea mays L.). Results show that the greenhouse gas (GHG) intensity of biopolyisoprene ( $\left.-4.59 \mathrm{~kg} \mathrm{CO}_{2} \mathrm{e} \mathrm{kg}^{-1}\right)$ is significantly lower than that of natural rubber (Hevea brasiliensis) and synthetic rubber $\left(-0.79\right.$ and $2.41 \mathrm{~kg} \mathrm{CO}_{2} \mathrm{e} \mathrm{kg}^{-1}$, respectively), while supporting a circular biogenic carbon economy. We found the land use intensity of bio-polyisoprene to be 0.25 ha metric ton $^{-1}$, which is $84 \%$ lower than that from rubber tree plantations. We compare the direct fermentation to isoprene results with indirect fermentation to isoprene through the intermediate, methyl butyl ether, where dehydration to isoprene is required. The direct fermentation of isoprene reduces reaction steps and unit operations, an expected outcome when employing process intensification, but our results show additional energy conservation and reduced contribution to climate change. Among the ReCiPe life cycle environmental impact metrics evaluated, air emission related impacts are high for bio-polyisoprene compared to those for natural and synthetic rubber. Those impacts can be reduced with air emission controls during production. All other metrics showed an improvement for bio-polyisoprene compared to natural and synthetic rubber.
\end{abstract}

Keywords: bio-polyisoprene; life cycle assessment; agricultural residues; circular economy

\section{Introduction}

Biological systems routinely use metabolic pathways to convert organic compounds to useful products. These pathways support functions within ecosystems where reactions are non-spontaneous. Metabolic processes enable the synthesis of specific substances needed for all organisms, including biochemicals, energy and fuel. The field of synthetic biology has adopted key processes from nature for industrial processing of chemical commodities. Advancing synthetic biology into industrial technological settings can allow for mapping of bio-based processes through metabolic engineering to create green, circular and more sustainable economies [1,2].

Synthetic biology has evolved from combining genes with E. coli organisms $[3,4]$ to focus more recently on technological aspects of creating bacterial genomes through computer simulations [5]. Biomass can be decomposed into fermentable sugars that can be tailor-made into bio-based monomers for polymers as successfully as the engineering of petrochemicals [6,7]. However, a key challenge is the realization of materials with comparable or even improved properties in terms of sustainability and economics. Improved pathways for metabolic engineering of the fermentation of sugars to fuels has given rise to higher yields and a more cost effective means of replacing petroleum sourced products [8,9], including biomass derived polymers. 
Polyisoprene, an organic polymer and much valued material found in natural rubber trees and certain plants (e.g., guayule, Parthenium argentatum), is used in the production of rubber products. Its molecular structure and high molecular weight offers material properties that are not easily replaced [10]. Current pathways for the production of polyisoprene rely either on rubber plantations, or more commonly synthetic routes in the conversion of low molecular weight hydrocarbon by-products of naphtha cracking [11]. In the production of natural rubber (Hevea brasiliensis), the polyisoprene polymer is sourced from mono-crop plantations that inherently destroy local ecosystems. Most of the world's tree-based polyisoprene production is in Southeast Asia, where new production growth imposes land use change, often from converting natural and managed forests to rubber plantations. This destroys the local ecosystem of flora and fauna and habitat for many species. The rate of deforestation in Southeast Asia due to rubber tree plantations is unprecedented in recent years $[12,13]$. Expanding the number of plantations by destroying native forests changes the soil microbiome, releasing GHGs from stored $\mathrm{C}$ and $\mathrm{N}$ as $\mathrm{CO}_{2}$ and $\mathrm{N}_{2} \mathrm{O}$, respectively [14]. On the other hand, petroleum-derived isoprene has a tremendous negative impact on climate change. Therefore, plantation- and petroleum-sourced polyisoprene both impose significant impacts on the environment. Direct fermentation of cellulosic sugars to isoprene for polyisoprene production may offer environmental and economic benefits as a replacement for rubber production from alternative routes.

Isoprene is a key intermediate chemical for the production of synthetic rubber (cispolyisoprene) in tire manufacturing. Although its main use is for the production of synthetic tires, other markets for polyisoprene include, adhesives, lubricants, and useful elastomers such as surgical gloves, golf balls and shoes [15]. With the rise in natural gas supply in the U.S. in the last decade, ethylene for polyethylene production has shifted away from the cracking of naphtha and gas oil to ethane cracking. This has drastically reduced the production of isoprene, a co-produced fraction of naphtha cracking, for synthetic rubber $[9,10]$. Additionally, isoprene produced from this unnatural route is energy intensive and involves multiple extraction and distillation unit processes to isolate isoprene in its pure form [6]. A decrease in isoprene supply from petroleum resources could also devastate native forests that would be required to fill the gap in demand for rubber and put a strain on the volatile market price of polyisoprene. The combined effects of declining supply from naphtha cracking and limitations on sustainably harvested rubber from plantations could lead to more viable, sustainable pathways in bio-based isoprene production [16].

In 2015, the global isoprene market was valued at USD 1.93 billion and was projected to grow to USD 3 billion market by 2021 [17]. Approximately $70 \%$ of isoprene production is used to manufacture polyisoprene from petroleum resources in the form of synthetic rubber. Moreover, synthetic-bio-polyisoprene can substitute for many existing applications of natural rubber. Today, the tire industry is experiencing higher demand due to growth in the automotive industry resulting in major companies like Goodyear, Bridgestone and Michelin choosing to partner with biotech companies to seek alternatives for isoprene supply [6]. Sustained demand for isoprene is expected to grow, given increased automotive sales in China and India, along with the exponential sales growth in the electric car industry [18]. Bio-based polyisoprene could supply the growing demand for fuel efficiency and eco-friendly tires $[18,19]$. However, the source and environmental impact of the isoprene should be scrutinized.

Recent studies have evaluated the life cycle environmental performance of producing natural rubber from guayule, a shrub native to the southwest U.S., as a substitute for Hevea natural rubbers. Growing guayule in suitable regions of the U.S. may limit U.S. dependence on imported natural rubber [20,21]; however, the land use requirements and GHG emissions resulting from irrigation, fertilizer usage, and other agricultural activities may be intensive for the growing the crop [22]. Additionally, land for guayule production could be limited such that resulting rubber production may not meet rising demand for diverse rubber products on a global scale. Thus, a diversity of sustainable feedstocks to supplement polyisoprene production is needed in the near term. 
Life cycle assessment (LCA) is an analytical method that can facilitate industrial decision making towards sustainable resource management. LCA is a standardized methodology that allows the compilation and evaluation of inputs, outputs and potential environmental impacts of a product system throughout its life cycle [23,24]. Prospective LCA [25] is increasingly used to evaluate the environmental tradeoffs of early-stage technology evolving at pre-commercial stages of development and at low technology readiness levels [26,27]. Riazi et al. [28] investigated the environmental tradeoffs of co-producing polyisoprene and renewable aviation fuel from process development unit scale experiments for a biorefinery concept that can flexibly convert isoprene to both final products. The authors undertook a prospective LCA of the two products and describe key experimental processes that tested the fermentation of sugars to methyl butenol (MBE) as an intermediate for isoprene. Yang et al. [29] demonstrated a laboratory-scale genetically engineered pathway in which direct fermentation to isoprene from sugars can negate this intermediate step. Our objective is to evaluate the life cycle environmental impacts of isoprene synthesis through direct fermentation, which reduces unit processes through process intensification, and may also reduce the impact of polyisoprene production through a synthetic biology route. We use a prospective LCA approach to investigate the variability in life cycle environmental impact of polyisoprene production from agricultural residues compared to natural and synthetic rubber. The direct fermentation of isoprene avoids the intermediate step of MBE dehydration by incorporating the advanced metabolic engineering pathway of direct fermentation to isoprene.

\section{Materials and Methods}

This study applies life cycle assessment (LCA) to evaluate the environmental impact associated with polyisoprene production from corn (Zea mays L.) stover based on experiments and chemical process simulations formulated with experimental data. We use mass and energy balances following methods set by the International Organization for Standardization [23] to construct a life cycle inventory (LCI) model using SimaPro 9.1 software [30]. The functional unit is defined as $1 \mathrm{~kg}$ of polyisoprene.

Life cycle impact assessment (LCIA) was carried out for ReCiPe mid-point impacts for producing polyisoprene from corn stover and compared to natural rubber, which was sourced from the GaBi 9 Professional LCA database [31] and synthetic rubber from ecoinvent [32]. ReCiPe mid-point impacts provide a holistic approach to compare the environmental, human health and ecosystem impacts in the production of polyisoprene from corn stover. These impacts have been applied in both Europe and North America to evaluate the life cycle environmental impacts of a wide range of product and engineering designs. Our goal is to use select ReCiPe mid-point impacts to evaluate a new production route for bio-based polyisoprene within a prospective LCA framework. We focus on climate change, land use, and ecosystem impacts deemed critical for a polymer production from agricultural resources, which occupy land but sequester $C$ during production.

Renewable polyisoprene is modeled as a cradle-to-gate process that includes feedstock production, harvest (where soil $\mathrm{N}_{2} \mathrm{O}$ emissions and change in soil organic carbon (SOC) are considered), transport of the feedstock, pretreatment, hydrolysis, fermentation, and polymerization to polyisoprene (Figure 1).

This study assumes that the polyisoprene product will be used for long-term goods that store the carbon sequestered via photosynthesis over the life-time of the material. We assumed that polyisoprene usage and end-of-life management were excluded from the defined life cycle system boundary involved in the biogenic carbon calculation.

The biorefinery is modeled to match the National Renewable Energy Laboratory's (NREL) biorefinery design [33] of 2500 metric tons (20\% moisture content) of biomass per day (MTPD). The supply of corn stover as the feedstock is assumed to be sourced within a $81 \mathrm{~km}$ (50 mile) radius of the biorefinery.

Data from previous literature [34,35] are used for certain LCI inputs (nutrients and diesel for farm operations) for corn stover harvesting and N-P-K nutrient addition to 
replace quantities in the biomass removed. Iowa was chosen as the location for corn stover supply to the biorefinery following the work of Pourhashem et al. [34], who used the DayCent biogeochemical model for Boone county, Iowa to estimate soil nitrous oxide and soil organic carbon (SOC) change emissions related to stover removal.

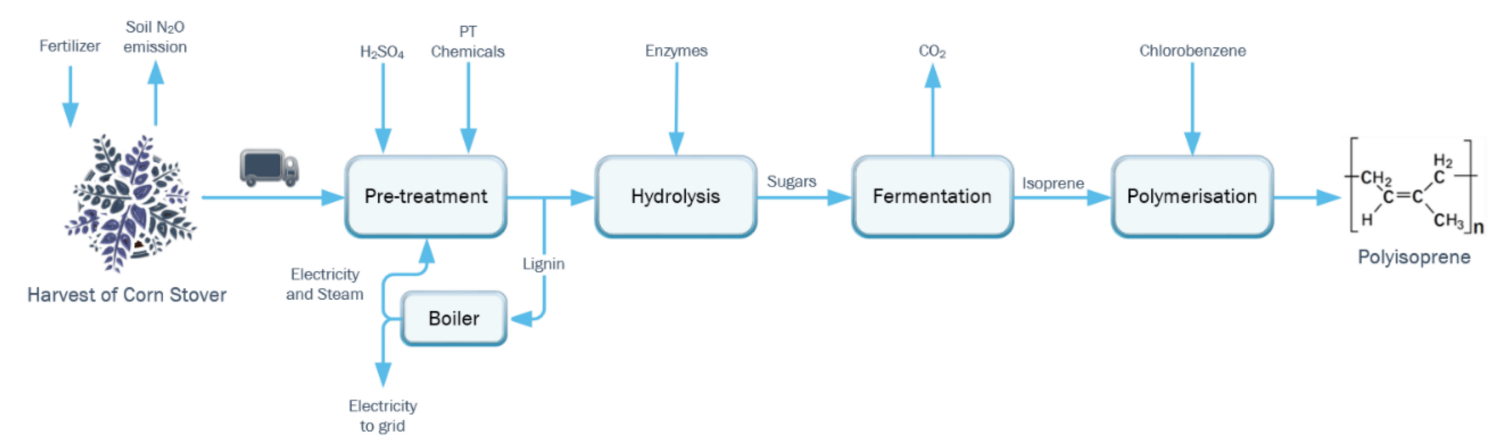

Figure 1. Cradle-to-gate life cycle process flow diagram for the production of polyisoprene from corn stover. Conversion of lignocellulosic sugars to Isoprene is simulated in UniSim design suite, which provides heat duties necessary for constructing the LCI model.

Specific areas of the biorefinery were modelled using experimental data to provide heat duty unit operations from UniSim simulation software and where data were unavailable, extensive mass and energy balances. Several unit operations for feedstock handling, pretreatment, and hydrolysis were taken from the literature $[28,34,35]$ to build mass balances to estimate the ReCiPe mid-point impacts that included loading of chemicals, enzymes and nutrients.

After the corn stover is brought to the biorefinery, pre-treatment and hydrolysis is carried out. Prior literature [28,34] was used for these steps assuming dilute acid pretreatment and enzymatic hydrolysis [33]. The lignin portion of the feedstock is assumed to be fractionated after pretreatment and combusted to generate electricity and steam onsite providing the energy required for the biorefinery similar to prior models $[33,35]$. The electricity generated is surplus to the operational needs of the biorefinery, providing an electricity credit that is assumed sold to the electricity grid, reducing the environmental and economic impact of the process [35,36]. The Midwest Reliability Organization (MRO) electricity grid, which supplies electricity to Iowa, is used for all LCA calculations.

The fermenter was modelled using UniSim chemical process simulation software (Figure 2). Dextrose, a native UniSim component, that has been used to model 6 carbon sugars was used as a feed along with air to supply oxygen. The feed temperature was considered at room temperature $20^{\circ} \mathrm{C}$ to match average yearly temperature in Iowa, US. The direct fermentation (DF) using genetically engineered E. coli converts sugar to isoprene using parameter conditions outlined in the dual MEP/MVA pathway [29] according to stoichiometry (Equation (1)).

$$
1.25 \mathrm{C}_{6} \mathrm{H}_{12} \mathrm{O}_{6}+0.5 \mathrm{O}_{2} \rightarrow \mathrm{C}_{5} \mathrm{H}_{8}+2.5 \mathrm{CO}_{2}+3.5 \mathrm{H}_{2} \mathrm{O}
$$

The fermentation process was scaled to a $100 \mathrm{~L}$ reactor operated at Technology Holding LLC laboratories to determine initial operating parameters and ensure that isoprene production is maintained in an environment to maximize its yield. Isoprene yields used in the process simulation and LCI are taken from experiments on the $100 \mathrm{~L}$ reactor and scaled-up through process simulation. The energy requirements for fermentation are dominated by the heat required to raise the feed temperature $\left(20^{\circ} \mathrm{C}\right)$ to the reactor temperature $\left(35^{\circ} \mathrm{C}\right)$. The fermenter reactor temperature was set at $35^{\circ} \mathrm{C}$ as isoprene changes to vapor phase at $34.1^{\circ} \mathrm{C}$ [37]. Using data from fermentation experiments, the heat duty required for this step is calculated using optimized process simulation in UniSim design suite [38]. Direct $\mathrm{CO}_{2}$ emissions from the fermentation step are calculated using the net stoichiometric 
fermentation reaction (Equation (1)). These emissions add to total GHG emissions of bioconversion and are related to biogenic carbon uptake of the feedstock. After exiting the fermenter, isoprene is recovered via a condenser and flash separator (Figure 2). The condenser modeling allows for heat duty calculations, however in the refinery alternative equipment such as a gas absorption unit may be used to separate $\mathrm{CO}_{2}$ and vapor impurities from the isoprene gas.

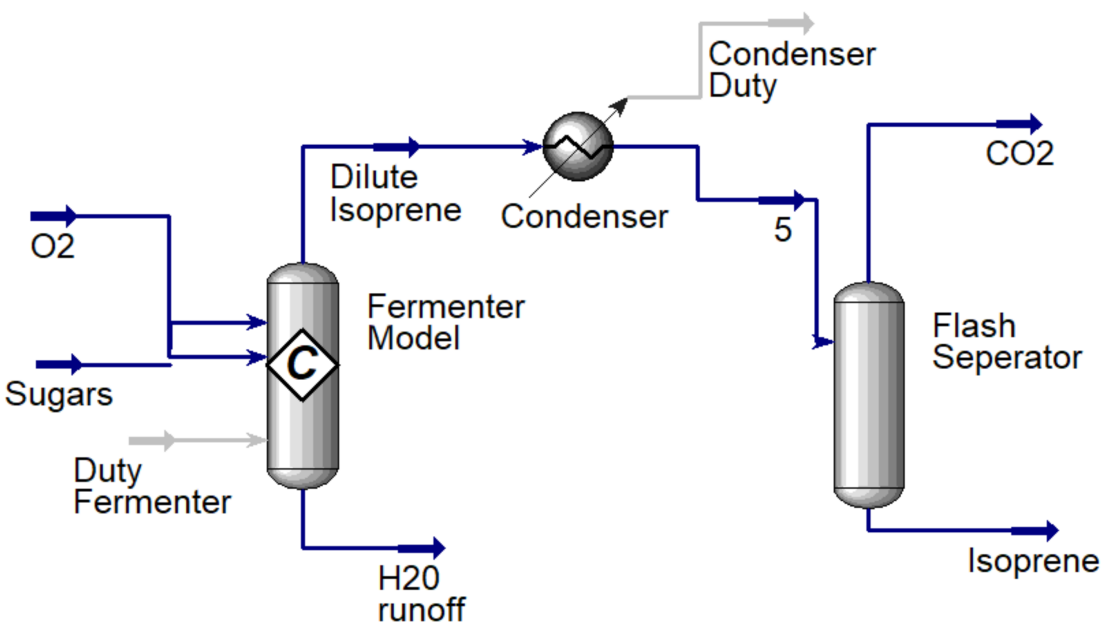

Figure 2. UniSim model of fermenter, condenser and flash separator.

The fermenter product stream consists of $26.7 \%$ isoprene by mass fraction and is condensed to purified isoprene in its liquid state where $\mathrm{CO}_{2}$ emissions are vented into the atmosphere. Heat integration between the fermenter reactor and condenser further reduces the energy and environmental impact of the process. Purified isoprene is then polymerized using industry standards and the assumption is that all isoprene would be used for polymerization to polyisoprene. The most effective polymerization of isoprene has been shown to take place at $70{ }^{\circ} \mathrm{C}$ using chlorobenzene as solvent [39]. Since the isoprene stream output from the condenser is $25^{\circ} \mathrm{C}$, a pre-heat step before polymerization is necessary to return the isoprene to gas phase at $70^{\circ} \mathrm{C}$, the energy requirement for which is calculated using UniSim. The energy required to polymerize isoprene is calculated using an activation energy of $3.3 \mathrm{kcal} / \mathrm{mol}$ based on literature [40].

We applied thermodynamic and kinematic equations to create material and energy balances around the biorefinery. Table 1 summarizes key parameters related to the unit operation temperature, fermenter and polymerization yields (by mass), thermal duties and surplus electricity produced by the lignin boiler.

Table 1. Parameter settings for Life Cycle Inventory.

\begin{tabular}{|c|c|c|c|}
\hline Parameter & Unit & Amount & Data sources and assumptions \\
\hline $\begin{array}{c}\text { Sugar yield from } \\
\text { pre-treatment and enzymatic } \\
\text { hydrolysis }\end{array}$ & g sugars/g feedstock & 0.597 & $\begin{array}{l}\text { National Renewable Energy Laboratory } \\
\text { (NREL) [33] }\end{array}$ \\
\hline Fermentation conversion & $\mathrm{g}$ isoprene/g sugars & 0.267 & $\begin{array}{c}\text { Modelled in UniSim using experimental data } \\
\text { from Yang et al. [29] }\end{array}$ \\
\hline Fermenter temperature & ${ }^{\circ} \mathrm{C}$ & 35 & Kirk-Othmer Encyclopedia [37] \\
\hline Heat duty in fermenter & $\mathrm{kJ} / \mathrm{kg}$ Isoprene & 1708 & Fermenter duty taken from UniSim simulation \\
\hline $\begin{array}{l}\text { Condenser duty after } \\
\text { fermenter }\end{array}$ & $\mathrm{kJ} / \mathrm{kg}$ Isoprene & 87.3 & Condenser duty taken from UniSim simulation \\
\hline Polymerization conversion & $\%$ & 99.9 & Experimental data from Alnajrani et al. [39] \\
\hline $\begin{array}{l}\text { Polymerization } \\
\text { activationenergy }\end{array}$ & $\mathrm{kcal} / \mathrm{mol}$ & 3.3 & Hadjichristidis et al. [40] \\
\hline $\begin{array}{l}\text { Surplus electricity } \\
\text { coproduct }\end{array}$ & $\mathrm{kWh} / \mathrm{kg}$ polyisoprene & 2.7 & $\begin{array}{l}\text { Reference calculated on assumption of selling } \\
\text { electricity coproduct to the grid }\end{array}$ \\
\hline
\end{tabular}


Table 2. summarizes the inputs of feedstock, chemicals, and energy on a functional unit basis of $1 \mathrm{~kg}$ polyisoprene. We assume that the corn stover supply shed yields meet the biorefinery feedstock demand and that there is no competition with other uses for the corn stover.

Table 2. LCI summary of cradle-to-gate feedstock, chemicals, and energy inputs and co-product outputs in the biorefinery. All data expressed per $1 \mathrm{~kg}$ Polyisoprene produced.

\begin{tabular}{ccc}
\hline Input & Quantity & Unit \\
\hline Corn stover (CS) feedstock & 5.53 & $\mathrm{~kg}$ \\
Feedstock yield & 9.7 & ton/ha/year \\
Collection & 1.7 & $\mathrm{MJ}$ \\
& $\mathrm{N} 27.7$ & $\mathrm{~g}$ \\
Nutrient replacement & $\mathrm{P} 10$ & $\mathrm{~g}$ \\
& $\mathrm{~K} 50.9$ & $\mathrm{~g}$ \\
$\mathrm{~N}_{2}$ O emissions & 305.8 & $\mathrm{~g}$ \\
Change in soil organic carbon & 1115.6 & $\mathrm{~g}$ \\
Transportation diesel & 25.7 & $\mathrm{~mL}$ \\
Enzymes & 50.9 & $\mathrm{~g}$ \\
Lime & 160.4 & $\mathrm{~g}$ \\
Diammonium phosphate & 10.5 & $\mathrm{~g}$ \\
Sulfuric acid & 143.8 & $\mathrm{kWh}$ \\
Oxygen from air & 0.142 & $\mathrm{~g}$ \\
\hline Output & 235 & \\
\hline Net co-produced electricity & & $\mathrm{kWh}$ \\
\hline
\end{tabular}

The 100-year global warming ReCiPe mid-point impacts follow the Intergovernmental Panel on Climate Change (IPCC) AR5 report, where the 100-year global warming potential (GWP) of $\mathrm{CO}_{2}, \mathrm{CH}_{4}$ and $\mathrm{N}_{2} \mathrm{O}$ gases have a GWP of 1,30 , and $265 \mathrm{~g} \mathrm{CO}_{2}$ equivalents $\left(\mathrm{CO}_{2} \mathrm{e}\right)$, respectively (Table 3). ReCiPe LCIA midpoint metrics for natural rubber were taken from the Gabi version 9 [31] professional database, described in [41], as a result of insufficient data in the ecoinvent database.

Table 3. Additional ReCiPe 2016 LCIA midpoint impacts considered.

\begin{tabular}{cc}
\hline Impact Category & Unit \\
\hline Fine particulate matter & PM2.5 equivalent \\
Stratospheric ozone depletion & $\mathrm{kg} \mathrm{CFC-11} \mathrm{equivalent}$ \\
Freshwater eutrophication & $\mathrm{kg}$ Phosphorous equivalent \\
Marine eutrophication & $\mathrm{kg}$ Nitrogen equivalent \\
Freshwater ecotoxicity & $\mathrm{kg} \mathrm{1,4-Dichlorobenzene} \mathrm{equivalent}$ \\
Marine ecotoxicity & $\mathrm{kg}$ 1,4-Dichlorobenzene equivalent \\
Human non-carcinogenic toxicity & $\mathrm{kg}$ 1,4-Dichlorobenzene equivalent \\
Terrestrial acidification & $\mathrm{kg}$ Sulfur Dioxide equivalent \\
Fossil depletion & $\mathrm{kg}$ oil equivalent \\
\hline
\end{tabular}

As the global population increases, demand for agricultural land for food production is expected to rise leading to rising competition for prime agricultural land [42]. A parallel assessment to GHG emissions is land use intensity as defined here for land required (in hectares) to produce $1 \mathrm{~kg}$ of polyisoprene. Land use scenarios have been evaluated according to Table 4, which summarizes data sources. The energy required for polymerization is taken from previous data obtained through process simulations and chemical kinetics equations, modeling the cracking of light naphtha, in a method similar to polymerization of isoprene from biomass [28]. The corn stover-to-polyisoprene pathway is based on removal of $50 \%$ corn stover from existing cropland in the US Midwest. 
Table 4. Description of model cases: DF, FMBE, NR, SR.

\begin{tabular}{cc}
\hline Pathway & Description $^{\mathbf{1}}$ \\
\hline DF & $\begin{array}{c}\text { Direct fermentation pathway of sugars to } \\
\text { isoprene. }\end{array}$ \\
FF-BC & $\begin{array}{c}\text { Direct fermentation pathway of sugars to } \\
\text { isoprene including biogenic carbon. } \\
\text { Indirect fermentation via methyl butenol } \\
\text { Indirect fermentation via methyl butenol } \\
\text { including biogenic carbon } \\
\text { FMBE-BC }\end{array}$ \\
NR & Natural rubber \\
NR-BC & Natural rubber including biogenic carbon \\
SR & Synthetic rubber \\
\hline
\end{tabular}

${ }^{1}$ DF and DF-BC scenarios based on models developed herein; FMBE and FMBE-BC scenarios from [28]; NR and NR-BC from evaluated from $\mathrm{GaBi}$; and SR evaluated from Ecoinvent.

The life cycle system boundary of natural rubber polyisoprene is taken from ReCiPe LCIA midpoint methods, and includes the impacts listed in Table 3. Table 4 summarizes the model cases compared for polyisoprene produced from direct fermentation of cellulosic sugars, converted from fermented MBE intermediate, and from natural rubber and synthetic rubber.

\section{Results and Discussion}

We evaluate contributions to and net life cycle global warming (GW) and land use impacts for four alternative rubber pathways and compare them to natural and synthetic rubber baselines. We further discuss and compare the LCIA midpoint impacts for the direct fermentation pathway modeled in this research relative to natural and synthetic rubber.

Figure 3 summarizes the life cycle global warming impacts of direct fermentation including (DF-BC) and excluding biogenic carbon (DF) sequestered in the final polyisoprene product. The figure also presents a comparison to previous work carried out by Riazi et al. (FMBE \& FMBE-BC). The GW estimates negative emissions only when sequestered biogenic $\mathrm{CO}_{2}$ is included (DF-BC and FMBE-BC). The higher isoprene yield in the DF-BC ( $-4.59 \mathrm{~kg} \mathrm{CO}_{2} \mathrm{e} / \mathrm{kg}$ polyisoprene) and $\mathrm{DF}\left(0.79 \mathrm{~kg} \mathrm{CO}_{2} \mathrm{e} / \mathrm{kg}\right.$ polyisoprene) pathways further reduces GW compared to the FMBE-BC and FMBE pathways, which emit -3.64 and $2.5 \mathrm{~kg} \mathrm{CO}_{2} \mathrm{e} / \mathrm{kg}$ polyisoprene, respectively. Additionally, reducing the unit steps involved in the DF production of isoprene, lowers the electrical and thermal demand of the biorefinery, which results in a lower environmental impact. At the same time, an increase surplus in electricity from the combustion of lignin provides a larger electricity credit in the overall life cycle. The GW impact pathway of DF at $0.79 \mathrm{~kg} \mathrm{CO}_{2} / \mathrm{kg}$ polyisoprene is lower than those of natural and synthetic rubber of 1.18 and $2.41 \mathrm{~kg} \mathrm{CO}_{2} / \mathrm{kg}$ polyisoprene, respectively. The bio-based polyisoprene is fully comprised of biogenic carbon. When accounting for biogenic carbon in bio-based materials two cases were considered. In the first case (DF-BC and FMBE-BC), biogenic carbon is accounted as carbon storage, $\mathrm{CO}_{2}$ that is captured from the atmosphere during photosynthesis and retained within the bio-based material over its product life. To be conservative, the benefits of biogenic carbon storage are not included in the second case (DF and FMBE), which leads to a net positive GW impact.

Figure 4a shows the major contributions to the GHG emissions not including the biogenic carbon and electricity credit, which are compared in Figure $4 \mathrm{~b}$. The hot spots in GHG emissions (Figure $4 \mathrm{a}$ ) are from the boiler and fermentation unit operations, both of which emit biogenic $\mathrm{CO}_{2}$ and represent $46 \%$ and $21 \%$ of GHG emissions, respectively. When summing the biogenic $\mathrm{CO}_{2}$ across the life cycle and applying a displacement credit for co-produced electricity, the life cycle GHG emissions are negative (DF-BC). Biogenic $\mathrm{CO}_{2}$ contributes over $40 \%$ of the negative GHG emissions (Figure $4 \mathrm{~b}$ ). The biogenic $\mathrm{CO}_{2}$ credit accounts for $-10.3 \mathrm{~kg} \mathrm{CO} 2 \mathrm{e}$ in the DF pathway along with a credit from the combustion of lignin in the boiler of $-2.0 \mathrm{~kg} \mathrm{CO}_{2} \mathrm{e}$. 


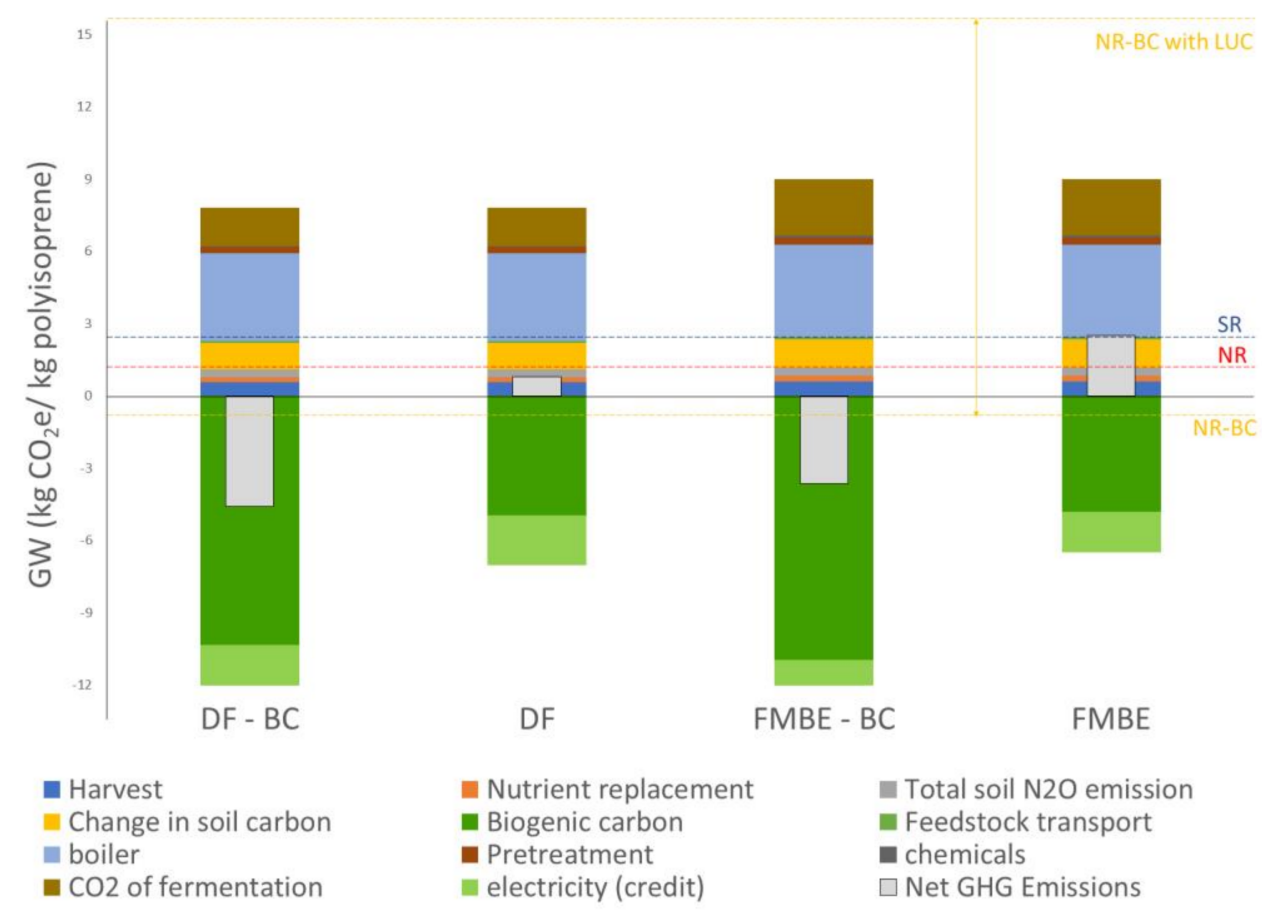

Figure 3. The 100-year GW of select parameters for the scenarios of producing polyisoprene, DF-BC= Direct fermentation with sequestered biogenic carbon; $\mathrm{DF}=$ direct fermentation without sequestered biogenic carbon; FMBE-BC = fermentation to methyl butenol with sequestered biogenic carbon; FMBE = fermentation methyl butenol without sequestered biogenic carbon; $\mathrm{SR}=$ synthetic rubber; $\mathrm{NR}=$ natural rubber; NR-BC = natural rubber with biogenic carbon; NR-BC = natural rubber including biogenic carbon and land use converted from forests to rubber plantations.

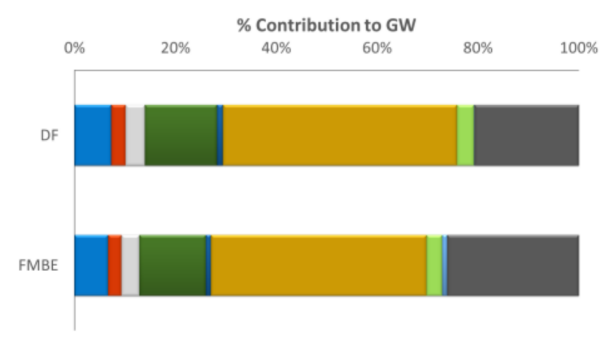

(a)

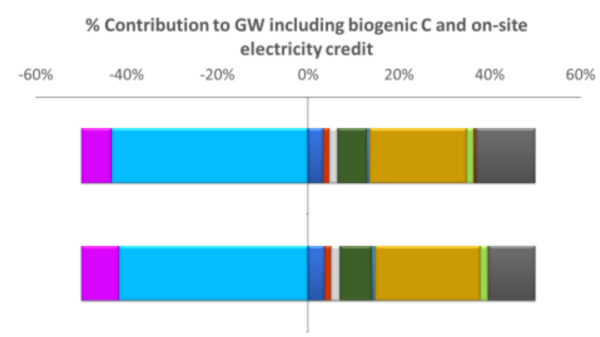

(b)

$\begin{array}{lll}\text { G Harvest } & \text { Nutrient replacement } & \square \text { Total soil N2O emission } \\ \text { Change in soil carbon } & \text { Feedstock transport } & \text { Boiler } \\ \text { Pretreatment } & \text { Chemicals } & \text { CO2 of fermentation } \\ \text { B Biogenic carbon } & \text { Electricity (credit) } & \end{array}$

Figure 4. Life cycle percentage component contribution (a) positive GW contributions to DF and FMBE process; (b) positive and negative GW contributions to DF and FMBE process including negative GWs of biogenic carbon and on-site electricity credit.

Recent studies $[43,44]$ have considered the production of value-added chemicals from lignin as opposed to sending the lignin to the boiler for on-site electricity and steam production. Lignin based chemicals, as a co-product in place of electricity, would remove the need for a boiler that is considered to run at low efficiency and high capital cost, as reported in [45]. Moreover, studies on ethanol biorefineries based on similar feedstock quantities have examined a reduction in boiler size by using the bio-gas produced onsite 
for thermal energy [39]. This may reduce capital costs significantly and provide alternative products from lignin.

The results documented in Table 5 show a decrease in GHG emissions to the atmosphere relative to the two main current sources of polyisoprene, natural rubber sourced from rubber plantations, and synthetic rubber sourced from petroleum. The land use intensity range for corn stover based polyisoprene, natural rubber and synthetic rubber are calculated based on previous studies reported by Riazi et al. [28] and Jawjit et al. [46] (Table 5). Corn stover as a feedstock is a by-product that relies on corn production markets; therefore, we assume that minimal additional land use would be required. The results of minimal land use suggest that only the replacement of nutrients would be a factor according to quantity of corn stover removed. Overall, land use intensity showed bio-based polyisoprene accounting for $0.25 \mathrm{ha} /$ metric ton, an $84 \%$ improvement from rubber tree plantations. A recent study [47] considered converting forests to new lands for new rubber tree plantations, due to increasing demand for polyisoprene. This leads to significant GHG emissions from deforestation, as the land clearing related GHG emissions are significant as described by de Blécourt et al. [48] for land use change of conversion of secondary forests to rubber. Therefore, from an environmental perspective, it may be more beneficial to use alternative biomass resources such as corn stover or forest residues that can be sustainably harvested to reduce the current pattern of deforestation.

Table 5. Land Use Intensity and GW of Polyisoprene Produced from Different Feedstocks.

\begin{tabular}{cccc}
\hline Feedstock Source & $\begin{array}{c}\text { Land Use (ha/Metric ton } \\
\text { Polyisoprene) }\end{array}$ & $\begin{array}{c}\text { Net GHG Emissions } \\
\text { (kg CO } \mathbf{2} / \mathbf{k g} \text { Polyisoprene) }\end{array}$ & $\begin{array}{c}\text { Net GHG Emissions } \\
\text { (kg CO } \mathbf{C}_{\mathbf{2}} \text { e/kg Polyisoprene) excl. } \\
\text { Biogenic Carbon }\end{array}$ \\
\hline DF & $0.25^{\mathrm{a}}$ to $0.59^{\mathrm{a}}$ & $-4.59^{\mathrm{a}}$ & $0.79^{\mathrm{a}}$ \\
FMBE & $0.3^{\mathrm{b}}$ to $0.7^{\mathrm{b}}$ & $-3.64^{\mathrm{a}}$ & $2.5^{\mathrm{a}}$ \\
NR & $1.6^{\mathrm{c}}$ & $-0.79^{\mathrm{d}}$ to $15.9^{\mathrm{b}}$ & $1.18^{\mathrm{d}}$ \\
SR & $0^{\mathrm{b}}$ & $2.41^{\mathrm{e}}$ & $2.41^{\mathrm{e}}$ \\
\hline
\end{tabular}

${ }^{a}$ Direct fermentation to isoprene. ${ }^{b}$ Riazi et al. [28] reported for indirect fermentation. ${ }^{\mathrm{c}}$ Jawjit et al. [46] reported. ${ }^{\mathrm{d}}$ Gabi 9 [31] reported

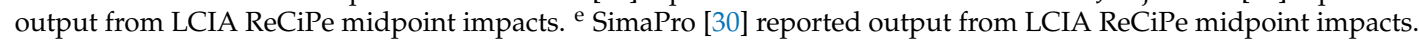

Based on our results, the GHG emissions for both NR and SR, only NR offers a route to a net carbon emission of zero or less at $-0.79 \mathrm{~kg} \mathrm{CO}_{2} \mathrm{e}$. However, this value is evaluated from LCA GaBi software data in which forest conversion from other land uses to growing rubber plantations is not considered. Including land use change, Jawgit et al. show that a likely upper bound of $15.9 \mathrm{~kg} \mathrm{CO}_{2} \mathrm{e}$ may offer a more realistic assessment of climate change affects when current demand would require mass forest conversion. From Table 5, negative emissions of $-4.59 \mathrm{~kg} \mathrm{CO}_{2}$ e from corn stover conversion to polyisoprene, via the DF pathway, offers a future alternative to rubber supply. This value is based on $50 \%$ corn stover removal; however, when greater removal occurs, this can have an adverse effect on the GHG emissions and would decrease land use by $57 \%$.

The purpose of bio-polyisoprene production is to use it as a substitute for rubber and thus reduce the global warming impacts. Therefore, the balancing of polyisoprene production and the overall carbon footprint is key to the development of the technology. The use of fermentable sugars from sustainably harvested biomass can be considered an environmentally preferable feedstock for its production. While the majority of current research on uses of biomass for petroleum substitution has focused on liquid fuels [34,35,49], novel bioconversion routes for polyisoprene production alone, shown here, offer the prospect of substituting the high in demand rubber materials. In this case, the stoichiometric isoprene yield for DF is greater than the indirect FMBE pathway that consists of further process units downstream to separate and purify isoprene before polymerization. Less feedstock is therefore needed to produce each $\mathrm{kg}$ of polyisoprene. This not only has an economic benefit to the process but also an environmental one. The potential impacts 
on other environmental categories are also important given complex technologies, use of chemicals, enzymes and the interactions metabolic pathways have with the local ecosystem.

The study by Riazi et al. [28] on bio-polyisoprene highlighted the need to incorporate multiple life cycle environmental impacts in addition to climate change. We evaluate several relevant midpoint LCIA impacts using ReCiPe 2016 for polyisoprene production (Figure 5) for the direct fermentation (DF) pathway alongside of the production of polyisoprene from natural rubber (NR) and synthetic rubber (SN). Supporting information Table S1 summarizes the contributions to the impacts by life cycle stage.

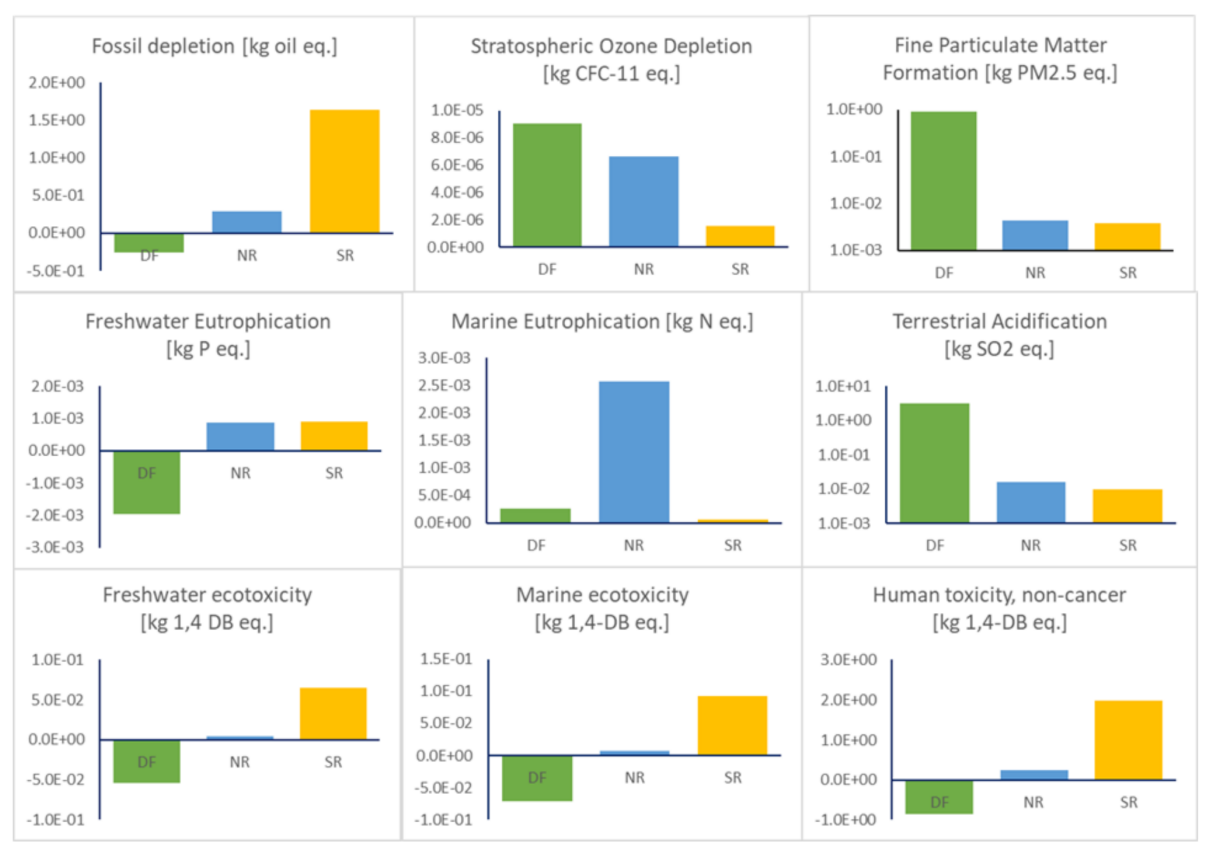

Figure 5. Life cycle environmental impacts of producing $1 \mathrm{~kg}$ of polyisoprene using ReCiPe 2016 midpoint impacts. The impacts for fine particular matter and terrestrial acidification are given in $\log$ scale on the y-axis.

Figure 5 shows that DF exerts a large environmental impact for terrestrial acidification. Those values are the result of inorganic emissions to air, particularly, $\mathrm{SO}_{2}$ at $2.4 \mathrm{~g} / \mathrm{kg}$ polyisoprene and both $\mathrm{CO}$ and $\mathrm{NO}_{x}$ at $1.1 \mathrm{~g} / \mathrm{kg}$ polyisoprene that have been calculated from boiler emissions. To counter these emissions, a vent scrubber could be installed as proposed by Larnaudie et al. [49]. NR is estimated to have a large impact in marine eutrophication. Our estimate is derived from the GaBi professional database based on production of latex rubber in Thailand; however, little information is provided on the processes that contribute to eutrophication. In contrast, Jawjit et al. [46] developed LCI data from four latex processing mills in Thailand. While they used an alternative indicator of eutrophication based on emissions of $\mathrm{PO}_{4}{ }^{3-}$, their research explained the major source of eutrophication impact originates from use of diammonium phosphate (DAP), which is used to remove magnesium from fresh latex. Synthetic rubber production from petroleum sources (SR) is shown to give best results for land use and ozone depletion. However, throughout the SR energy intensive process from cradle to gate, GHG emissions are larger compared to all pathways when including biogenic $\mathrm{CO}_{2}$ benefits. In addition, SR has an impact of $1.63 \mathrm{~kg}$ oil equivalent for fossil depletion per $\mathrm{kg}$ of polyisoprene produced. Crude oil, the most common raw material in SR production, accounts for $71 \%$ of this value. DF is not sourced from crude oil or from plantations and therefore has the potential to minimize fossil depletion, ecotoxicity and climate change.

While a number of environmental savings can be achieved, stratospheric ozone depletion is the main environmental burden from DF when considered in a comparison. This is likely caused by biomass transport [50]. GaBi and ecoinvent datasets do not appear to 
have inputs for fine particulate matter formation for NR and SR and this is something that should be considered. Studies characterizing the health effects of $\mathrm{PM}_{2.5}$ are becoming more frequent in LCA research and therefore more detailed analysis of this impact area should be performed. Health effects of $\mathrm{PM}_{2.5}$ calculated with the ReCiPe 2016 method using LCA software are much lower in NR and SR, which could be related in part to underestimation of data used to calculate the results of fine particulate matter.

With supply uncertainty of polyisoprene in the near-future, fermentable sugar from sustainably harvested biomass has been considered an environmentally preferable feedstock for its production. Synthetic bioconversion routes such as the direct fermentation pathway to isoprene for polyisoprene production offers the prospect of substituting for rubber-based materials. However, synthetic polyisoprene and bio-polyisoprene cannot fully substitute for natural latex rubber in all applications due to limitations in material properties like elasticity, abrasion resistance [51]. Given that bioconversion technologies are at an early stage of development, at precommercial scales, there are technological challenges affecting the profitability and hence commercialization of such biorefineries. To assess its commercialization potential, a techno-economic analysis of this proposed process for bio-polyisoprene is needed to understand its economic viability along with environmental benefit.

\section{Conclusions}

This LCA study highlights the potential for producing a sustainable alternative to natural and synthetic rubber supply given its anticipated growth in demand in the future. A new, early technology pathway is explored using corn stover as a biomass feedstock. Analyzing processes through chemical process modeling and simulation, we develop a life cycle inventory of an optimized fermenter that converts cellulose and hemicellulose sugars to isoprene to produce polyisoprene. When comparing this biomass conversion pathway for polyisoprene to synthetic and natural rubber pathways, we find a significant reduction in GHG emissions to $-4.59 \mathrm{~kg} \mathrm{CO}_{2} \mathrm{e} / \mathrm{kg}$ polyisoprene. Besides a decrease in GHG emissions, the increased demand for polyisoprene could lead to further expansion of mono-crop rubber plantations, which is destroying ecosystems through mass deforestation. Sustainable sources of biomass for bio-polyisoprene production could have a role in arresting this impact through sourcing biomass from agricultural residues on existing agricultural land with a significantly lower land use intensity of $0.25 \mathrm{ha} / \mathrm{metric}$ tonne polyisoprene. Petroleum sourced polyisoprene, although having a low land use intensity, primarily continues to consume fossil energy resources, contribute more greatly to global warming and affect human and ecosystem health through toxic emissions. Direct fermentation to isoprene for the production of polyisoprene results in negative fossil energy depletion, freshwater eutrophication, human toxicity and terrestrial and marine ecotoxicity due to electricity co-product credits. It reduces marine eutrophication as compared to current sources of polyisoprene but releases higher fine particulate matter and results in greater terrestrial acidification and stratospheric ozone depletion due to air emissions at the isoprene biorefinery. Controls on air emissions could help mitigate those impacts and should be investigated through more detailed process design and equipment selection.

Process modeling and simulation enabled predicting the environmental performance of the isoprene fermenter studied herein through LCA. The process modeling approach performed in this research suggests potential for a low environmental impact alternative pathway for producing bio-polyisoprene to support future demand and for renewable rubber. Although, current research still focuses on uses of biomass for replacement in petroleum-based liquid fuels, novel bioconversion routes for polyisoprene production alone offer an alternative prospect for rubber-based materials.

Supplementary Materials: The following are available online at https: / / www.mdpi.com/article/1 0.3390/fermentation7040204/s1, Table S1: Contributions to the LCIA metrics by life cycle stage. 
Author Contributions: Conceptualization, S.S. and M.K.; methodology, S.S., R.B., M.K.; formal analysis, R.B.; investigation, R.B.; resources, S.S.; data curation, R.B., M.K., S.S.; writing-original draft preparation, R.B.; writing-review and editing, R.B., M.K., S.S.; visualization, R.B.; supervision, S.S.; project administration, S.S.; funding acquisition, S.S. All authors have read and agreed to the published version of the manuscript.

Funding: This research was funded by the Israel Science Foundation, grant number ISF 1484/20 and the U.S. Department of Energy, grant number DE-SC0013230.

Institutional Review Board Statement: Not applicable.

Informed Consent Statement: Not applicable.

Data Availability Statement: The data presented in this study are available in tables and figures presented in the manuscript and supplementary material.

Acknowledgments: S.S. acknowledges support from the Technion Women's Advancement Chair.

Conflicts of Interest: The authors declare no conflict of interest.

\section{References}

1. Lee, J.W.; Na, D.; Park, J.M.; Lee, J.; Choi, S.; Lee, S.Y. Systems metabolic engineering of microorganisms for natural and non-natural chemicals. Nat. Chem. Biol. 2012, 8, 536-546. [CrossRef] [PubMed]

2. Kim, G.B.; Kim, W.J.; Kim, H.U.; Lee, S.Y. Machine learning applications in systems metabolic engineering. Curr. Opin. Biotechnol. 2020, 64, 1-9. [CrossRef] [PubMed]

3. Elowitz, M.B.; Leibler, S. A synthetic oscillatory network of transcriptional regulators. Nat. Cell Biol. 2000, 403, 335-338. [CrossRef] [PubMed]

4. Gardner, T.S.; Cantor, C.R.; Collins, J.J. Construction of a genetic toggle switch in Escherichia coli. Nat. Cell Biol. 2000, 403, 339-342. [CrossRef] [PubMed]

5. Venetz, J.E.; Del Medico, L.; Wölfle, A.; Schächle, P.; Bucher, Y.; Appert, D.; Tschan, F.; Flores-Tinoco, C.E.; van Kooten, M.; Guennoun, R.; et al. Chemical synthesis rewriting of a bacterial genome to achieve design flexibility and biological functionality. Proc. Natl. Acad. Sci. USA 2019, 116, 8070-8079. [CrossRef]

6. Heracleous, E.; Pachatouridou, E.; Louie, L.; Dugar, D.; Lappas, A.A. Efficient Route for the Production of Isoprene via Decarboxylation of Bioderived Mevalonolactone. ACS Catal. 2020, 10, 9649-9661. [CrossRef]

7. Zhao, Y.; Yang, J.; Qin, B.; Li, Y.; Sun, Y.; Su, S.; Xian, M. Biosynthesis of isoprene in Escherichia coli via methylerythritol phosphate (MEP) pathway. Appl. Microbiol. Biotechnol. 2011, 90, 1915-1922. [CrossRef] [PubMed]

8. Jeffries, T.W.; Jin, Y.-S. Metabolic engineering for improved fermentation of pentoses by yeasts. Appl. Microbiol. Biotechnol. 2004, 63, 495-509. [CrossRef]

9. Dharmadi, Y.; Murarka, A.; Gonzalez, R. Anaerobic fermentation of glycerol by Escherichia coli: A new platform for metabolic engineering. Biotechnol. Bioeng. 2006, 94, 821-829. [CrossRef]

10. Mooibroek, H.; Cornish, K. Alternative sources of natural rubber. Appl. Microbiol. Biotechnol. 2000, 53, 355-365. [CrossRef]

11. Isikgor, F.H.; Becer, C.R. Lignocellulosic biomass: A sustainable platform for the production of bio-based chemicals and polymers. Polym. Chem. 2015, 6, 4497-4559. [CrossRef]

12. Ahrends, A.; Hollingsworth, P.M.; Ziegler, A.D.; Fox, J.; Chen, H.; Su, Y.; Xu, J. Current trends of rubber plantation expansion may threaten biodiversity and livelihoods. Glob. Environ. Chang. 2015, 34, 48-58. [CrossRef]

13. Warren-Thomas, E.M.; Edwards, D.P.; Bebber, D.P.; Chhang, P.; Diment, A.N.; Evans, T.D.; Lambrick, F.; Maxwell, J.F.; Nut, M.; O'Kelly, H.J.; et al. Protecting tropical forests from the rapid expansion of rubber using carbon payments. Nat. Commun. 2018, 9, 911. [CrossRef] [PubMed]

14. Kaupper, T.; Hetz, S.; Kolb, S.; Yoon, S.; Horn, M.A.; Ho, A. Deforestation for oil palm: Impact on microbially mediated methane and nitrous oxide emissions, and soil bacterial communities. Biol. Fertil. Soils 2020, 56, 287-298. [CrossRef]

15. Morais, A.; Dworakowska, S.; Reis, A.; Gouveia, L.; Matos, C.T.; Bogdał, D.; Lukasik, R. Chemical and biological-based isoprene production: Green metrics. Catal. Today 2015, 239, 38-43. [CrossRef]

16. Bruijnincx, P.C.A.; Weckhuysen, B.M. Shale Gas Revolution: An Opportunity for the Production of Biobased Chemicals? Angew. Chem. Int. Ed. 2013, 52, 11980-11987. [CrossRef]

17. Markets and Markets. Isoprene Market by Type (Polymer grade, Chemical grade), Application (Polyisoprene, Styrene Isoprene Styrene, Isobutyl Isoprene Rubber), End-Use Industry (Tires, Non-tires, Adhesives), and Region-Global Forecast to 2021 Title. 2017. Available online: https://www.researchandmarkets.com/reports/4209856/isoprene-market-by-type-polymer-grade-c hemical (accessed on 12 September 2021).

18. IEA. Global EV Outlook 2020: Entering the Decade of Electric Drive? OECD: Paris, France, 2020; p. 276.

19. Asghar, U.; Masoom, A.; Javed, A.; Abbas, A. Economic Analysis of Isoprene Production from Good Year Scientific Process. Am. J. Chem. Eng. 2020, 8, 63. [CrossRef] 
20. Luo, Z.; Abdel-Haleem, H. Phenotypic diversity of USDA guayule germplasm collection grown under different irrigation conditions. Ind. Crop. Prod. 2019, 142, 111867. [CrossRef]

21. Bhadra, S.; Mohan, N.; Parikh, G.; Nair, S. Possibility of artocarpus heterophyllus latex as an alternative source for natural rubber. Polym. Test. 2019, 79, 106066. [CrossRef]

22. Soratana, K.; Rasutis, D.; Azarabadi, H.; Eranki, P.L.; Landis, A.E. Guayule as an alternative source of natural rubber: A comparative life cycle assessment with Hevea and synthetic rubber. J. Clean. Prod. 2017, 159, 271-280. [CrossRef]

23. ISO. ISO 14040:2006-Environmental Management-Life Cycle Assessment-Principles and Framework. Available online: https: / / www.iso.org/standard/37456.html (accessed on 9 October 2020).

24. ISO. ISO 14044:2006-Environmental Management—Life Cycle assessment-Requirements and Guidelines. Available online: https://www.iso.org/standard/38498.html (accessed on 9 October 2020).

25. Arvidsson, R.; Tillman, A.; Sandén, B.A.; Janssen, M.; Nordelöf, A.; Kushnir, D.; Molander, S. Environmental Assessment of Emerging Technologies: Recommendations for Prospective LCA. J. Ind. Ecol. 2018, 22, 1286-1294. [CrossRef]

26. Thomassen, G.; Van Dael, M.; Van Passel, S.; You, F. How to assess the potential of emerging green technologies? Towards a prospective environmental and techno-economic assessment framework. Green Chem. 2019, 21, 4868-4886. [CrossRef]

27. Sorunmu, Y.; Billen, P.; Spatari, S. A review of thermochemical upgrading of pyrolysis bio-oil: Techno-economic analysis, life cycle assessment, and technology readiness. GCB Bioenergy 2020, 12, 4-18. [CrossRef]

28. Riazi, B.; Karanjikar, M.; Spatari, S. Renewable Rubber and Jet Fuel from Biomass: Evaluation of Greenhouse Gas Emissions and Land Use Trade-offs in Energy and Material Markets. ACS Sustain. Chem. Eng. 2018, 6, 14414-14422. [CrossRef]

29. Yang, C.; Gao, X.; Jiang, Y.; Sun, B.; Gao, F.; Yang, S. Synergy between methylerythritol phosphate pathway and mevalonate pathway for isoprene production in Escherichia coli. Metab. Eng. 2016, 37, 79-91. [CrossRef] [PubMed]

30. Pre Consultants, SimaPro 9.1. 2020. Available online: https://simapro.com/wp-content/uploads/2020/10/FullUpdateInstructi onsToSimaPro911.pdf (accessed on 21 September 2021).

31. Sphera Gabi 9. Life Cycle Assessment LCA Software. 2020. Available online: http://www.gabi-software.com/international/inde $\mathrm{x} /$ (accessed on 9 October 2020).

32. Wernet, G.; Bauer, C.; Steubing, B.; Reinhard, J.; Moreno-Ruiz, E.; Weidema, B. The ecoinvent database version 3 (part I): Overview and methodology. Int. J. Life Cycle Assess. 2016, 21, 1218-1230. [CrossRef]

33. Humbird, D.; Davis, R.; Tao, L.; Kinchin, C.; Hsu, D.; Aden, A.; Schoen, P.; Lukas, J.; Olthof, B.; Worley, M.; et al. Process Design and Economics for Conversion of Lignocellulosic Biomass to Ethanol; NREL Technical Report; NREL/TP-5100-51400; National Renewable Energy Laboratory: Golden, CO, USA, 2011; Volume 303, pp. 1-176. Available online: http:/ /www.osti.gov/bridge (accessed on 15 March 2021).

34. Pourhashem, G.; Adler, P.R.; McAloon, A.J.; Spatari, S. Cost and greenhouse gas emission tradeoffs of alternative uses of lignin for second generation ethanol. Environ. Res. Lett. 2013, 8, 025021. [CrossRef]

35. Spatari, S.; Bagley, D.; MacLean, H.L. Life cycle evaluation of emerging lignocellulosic ethanol conversion technologies. Bioresour Technol. 2010, 101, 654-667. [CrossRef]

36. MacLean, H.L.; Spatari, S. The contribution of enzymes and process chemicals to the life cycle of ethanol. Environ. Res. Lett. 2009, 4. [CrossRef]

37. Lybarger, H.M. Isoprene. In Kirk-Othmer Encyclopedia of Chemical Technology; John Wiley \& Sons, Inc.: Hoboken, NJ, USA, 2000.

38. Honeywell. UniSim Process Design Suite; Honeywell: Calgary, AB, Canada, 2021.

39. Alnajrani, M.N.; Mair, F.S. Bidentate forms of $\beta$-triketimines: Syntheses, characterization and outstanding performance of enamine-diimine cobalt complexes in isoprene polymerization. Dalton Trans. 2016, 45, 10435-10446. [CrossRef]

40. Hadjichristidis, N.; Roovers, J.E.L. Synthesis and solution properties of linear, four-branched, and six-branched star polyisoprenes. J. Polym. Sci. Polym. Phys. Ed. 1974, 12, 2521-2533. [CrossRef]

41. Spatari, S.; Betz, M.; Florin, H.; Baitz, M.; Faltenbacher, M. Using GaBi 3 to perform life cycle assessment and life cycle engineering. Int. J. Life Cycle Assess. 2001, 6, 81-84. [CrossRef]

42. Ciliberti, C.; Jordaan, S.M.; Smith, S.V.; Spatari, S. A life cycle perspective on land use and project economics of electricity from wind and anaerobic digestion. Energy Policy 2016, 89, 52-63. [CrossRef]

43. Xu, C.C.; Dessbesell, L.; Zhang, Y.; Yuan, Z. Lignin valorization beyond energy use: Has lignin's time finally come? Biofuels Bioprod. Biorefin. 2021, 15, 32-36. [CrossRef]

44. Belaud, J.-P.; Prioux, N.; Vialle, C.; Buche, P.; Destercke, S.; Barakat, A.; Sablayrolles, C. Intensive Data and Knowledge-Driven Approach for Sustainability Analysis: Application to Lignocellulosic Waste Valorization Processes. Waste Biomass Valoriz. 2021, 1, 1-16. [CrossRef]

45. Davis, R.E.; Grundl, N.J.; Tao, L.; Biddy, M.J.; Tan, E.C.; Beckham, G.T.; Humbird, D.; Thompson, D.N.; Roni, M.S. Process Design and Economics for the Conversion of Lignocellulosic Biomass to Hydrocarbon Fuels and Coproducts: 2018 Biochemical Design Case Update: Biochemical Deconstruction and Conversion of Biomass to Fuels and Products via Integrated Biorefinery Path. 2018; p. 147. Available online: www.nrel.gov/publications (accessed on 21 April 2021).

46. Jawjit, W.; Pavasant, P.; Kroeze, C. Evaluating environmental performance of concentrated latex production in Thailand. J. Clean. Prod. 2015, 98, 84-91. [CrossRef]

47. Jawjit, W.; Kroeze, C.; Rattanapan, S. Greenhouse gas emissions from rubber industry in Thailand. J. Clean. Prod. 2010, 18, 403-411. [CrossRef] 
48. De Blécourt, M.; Brumme, R.; Xu, J.; Corre, M.D.; Veldkamp, E. Soil Carbon Stocks Decrease following Conversion of Secondary Forests to Rubber (Hevea brasiliensis) Plantations. PLoS ONE 2013, 8, e69357. [CrossRef]

49. Larnaudie, V.; Bule, M.; San, K.-Y.; Vadlani, P.V.; Mosby, J.; Elangovan, S.; Karanjikar, M.; Spatari, S. Life cycle environmental and cost evaluation of renewable diesel production. Fuel 2020, 279, 118429. [CrossRef]

50. Zhang, Y.; Hu, G.; Brown, R.C. Life cycle assessment of the production of hydrogen and transportation fuels from corn stover via fast pyrolysis. Environ. Res. Lett. 2013, 8, 025001. [CrossRef]

51. Cornish, K. Similarities and differences in rubber biochemistry among plant species. Phytochemistry 2001, 57, 1123-1134. [CrossRef] 